\title{
Kriza etički neutralne znanosti
}

\author{
Mile Babić
}

Sažetak: Današnja kriza morala u znanstveno-tehničkoj civilizaciji vodi nas u zajedničku propast, jer je suvremena znanost (koja je slobodna od morala) nerazdvojivo povezana s tehnikom, pa se može nazivati tehnoznanost. Kao takva ona ima danas monopol na znanje o svijetu te zbog toga posjeduje najveću moć u dosadašnjoj povijesti i u tijesnoj je sprezi s nosiocima moći: s ekonomijom, politikom, medicinom, medijima, državama i međunarodnim kompanijama. Imati najveću zamislivu moć (koja, po Kantu, kvari slobodu umnoga rasuđivanja), a pritom biti slobodan od morala koji ograničuje tu moć, znači pretvoriti svijet u svijet najmodernijeg barbarstva i nasilja, uništenja i samouništenja. Samo moralno odgovorna znanost sposobna je za budućnost i ona je pretpostavka civilizacije sposobne za budućnost. Samo odgovorna znanost može spriječiti pretvaranje znanosti u sveobuhvatnu dogmu. Stoga znanost mora biti slobodna od svake ideologije koja prikazuje stvarnost crno-bijelom tehnikom te tako proizvodi taštinu, mržnju i nasilje. Globalna znanost zahtijeva globalni etos (globalnu odgovornost). Znanosti je stalo do istine koja nas oslobađa od laži i povezuje nas u jednu zajednicu. Temeljni etički imperativ primum non nocere ('najprije ne škoditi životu') vrijedi svuda i zauvijek. Etički odgovorna znanost zahtijeva promjenu svijesti pojedinca i ponovno otkrivanje ideje bratstva. Nijedno ljudsko djelovanje postojeću stvarnost ne smije razarati i uništavati, nego je mora usavršavati.

Ključne riječ: znanost, kriza etički neutralne znanosti, etički odgovorna znanost, globalna moć, globalna odgovornost, temeljni etički imperativ, nova ideja bratstva

\section{Uvod}

U ovom ću radu najprije u uvodu izložiti kako je Alexander Görlach ustvrdio da nitko - ni ljudi ni institucije - nije razumio težinu financijske krize 2008. godine u Sjedinjenim Američkim Državama zato što je svima bila vidljiva samo materijalna strana krize, a duhovna (moralna) nije bila zamijećena. Nitko, dakle, nije primijetio duhovni (moralni) uzrok krize, najveće nakon Velike depresije (1929-1933). Zatim ću pokazati što kažu suvremeni, svjetski relevantni mislioci o tome kako je došlo do duboke krize morala (do njegova skoroga nestanka) na svim područjima i razinama ljudskog života. Pritom se

*Dopisni član Akademije nauka i umjetnosti Bosne i Hercegovine.
E-mail: dekan.babic@gmail.com 
postavlja pitanje je li to kraj humanuma, tj. kraj čovjeka. Nakon toga treba reći da danas svjetski priznat njemački moralni filozof Otfried Höffe ističe da svakom obliku znanosti mora korespondirati odgovarajući oblik etike tijekom povijesti. Höffe razlikuje pet faza u razvoju znanosti i njoj odgovarajuće etike. Naposljetku, valja naglasiti da Günther Mack, umirovljeni profesor eksperimentalne fizike u njemačkom Tübingenu, dokazuje da je potrebno umjesto znanosti slobodne od vrijednosti (tj. od morala i etike) uspostaviti znanost koja će biti odgovorna individualno, institucionalno i javno; umjesto dosadašnje paradigme znanosti slobodne od morala uspostaviti paradigmu znanosti sposobnu za budućnost.

Kao uvod u temu navodim tvrdnju Alexandera Görlacha (lingvista, teologa, gostujućeg profesora na Harvardu i Cambridgeu, te profesora etike i teologije u njemačkom Lüneburgu) iz njegove knjige Homo empathicus (usp. Görlach 2019: 29), koja glasi da nijedan političar, nijedna vlada i nijedan nadnacionalni entitet nisu razumjeli težinu financijske krize nastale 2008 . godine kad je bankrotirala Banka Lehman Brothers u Sjedinjenim Američkim državama. Svi su gledali samo materijalnu stranu novonastale krize, a nisu tražili njezin duhovni uzrok koji je zove pohlepa, jedan od sedam smrtnih grijeha po kršćanskom nauku. Nijedno društvo ne može opstati ako glavni poroci (oholost, pohlepa, pohota, zavist, srditost, lijenost), tvrdi Görlach, određuju djelovanje njegovih članova, a to tvrdi oslanjajući se na tekst Ralfa Dahrendorfa, njemačko-britanskoga sociologa, filozofa, ekonomiste i političara (usp. Dahrendorf 2009), koji pak konstatira da privredni sustav danas razara svoje vlastite mentalitetske pretpostavke. Dahrendorf nas podsjeća da je prvi oblik kapitalizma (Sparkapitalismus, kapitalizam štednje) bio utemeljen na Calvinovoj protestantskoj etici, kako je to dokazao veliki njemački sociolog Max Weber u svom djelu Protestantska etika i duh kapitalizma. Naime, Dahrendorf ističe da se korijeni ekonomskog mišljenja nalaze u moralnoj filozofiji jer čovjek koji privređuje, utemeljuje svoje djelovanje na određenim vrijednostima. Kao primjer on navodi Adama Smitha, škotskog ekonomistu i etičara, koji tvrdi da je temelj moralne filozofije čovjek, a ne tržište (ne kapital i ne profit). Kratko rečeno, suvremena ekonomija odvojila se od morala i postala važnijom od njega. Dahrendorf analizira tri oblika kapitalizma. U prvom obliku (kapitalizmu štednje) poštuje se etika, a u drugom (Konsumkapitalismus, potrošački kapitalizam) već je važnija potrošnja od poštenoga rada, dok u trećem (Pumpkapitalismus, kapitalizam pozajmljenog novca) ljudi žive od potrošnje novca koji su pozajmili od banaka, koji nisu zaradili i koji ostaje bez pokrića. Glavna deviza kapitalizma pozajmljenog 
novca glasi: Enjoy, pay later (Uživaj sada, a plati kasnije). Dubina i silovitost spomenute financijske krize sastojala se u tome da su akteri financijskoga sustava apsolutizirali svoje probitke (dobili su velike otpremnine) te nisu pokazali ni osobnu i sustavnu odgovornost. Nitko nije sankcioniran, jer nijedna država nije stajala iza toga financijskog sustava. Iz toga slijedi da cijeli sustav treba temeljito reformirati na osnovi glavnih moralnih vrijednosti (usp. Görlach 2019: 16-19, 21-36).

\section{Kriza morala na svim područjima i razinama ljudskog života}

Nakon uvoda izlažem stajališta i tvrdnje svjetski relevantnih mislilaca o krizi morala i o predvidivom nestanku morala iz svih područja i sa svih razina ljudskoga života te iz svih dijelova kulture, počevši od znanosti, pa do umjetnosti i religije. Oslanjam se na sljedeće autore: Charles Taylor, Pascal Bruckner, Robert N. Bellah, Peter Sloterdijk, Hans Jonas, Edgar Morin, Hans Küng, Žarko Paić, Jürgen Habermas, Yuval Noah Harari, Otfried Höffe i Günther Mack.

\section{A. Charles Taylor}

Kanadski svjetski priznat filozof, professor emeritus, uza sve ostalo poznat po vlastitom doprinosu moralnoj filozofiji. U svojoj izvrsnoj knjizi Quellen des Selbst [Izvori sebstva] (Taylor 1994) pokazao je kako su nastala dva novovjekovna individualizma. Začetnik prvoga (racionalnoga) individualizma bio je René Descartes, a drugoga (ekspresivnog) Michel de Montaigne. Za Descartesa čovjek je čisti um, i to dezangažirani um, koji je odijeljen od tijela. Takav um ima instrumentalan odnos prema vlastitom tijelu i prema ukupnoj stvarnosti: on vlada nad svime i odgovoran je samome sebi. De Montaigneov ekspresivni individualizam želi izraziti čovjekovu originalnost, posebnost $i$ neponovljivost. Takav je individualizam emotivan, jer izražava čovjekove težnje i želje, tj. posebnost čovjekova osjećanja, ali on potiskuje moralnu ontologiju, što znači da čini nemogućim moral kao teoriju i kao praksu. Oba individualizma, po Tayloru, zanemaruju moralnu dimenziju ljudskoga bića i ne pitaju o biti dobroga života niti o tome po čemu je ljudski život vrijedan življenja. Također, Taylor pokazuje da oba individualizma sadržavaju stanovite moralne imperative i norme, ali im nedostaje ontološko utemeljenje moralnih normi. Oba su individualizma okrenuta prema čovjekovoj unutrašnjosti. 
Descartes ističe ono što je svim ljudima zajedničko (um), a de Montaigne ono po čemu je svaki čovjek poseban.

U knjizi Negative Freiheit? [Negativna sloboda?] (Taylor 1998) kritizira novovjekovni individualizam te pokazuje u čemu je zabluda negativne slobode. Naime, u liberalnom društvu sloboda se shvaća isključivo kao neovisnost individuuma o drugima, kao odsutnost vanjskih fizičkih i zakonskih zapreka. Treba reći da uz vanjske zapreke postoje i unutrašnje. Za unutrašnje zapreke najviši je sudac sam subjekt, što isključuje mogućnost da o njegovu djelovanju sude vanjski subjekti. Iz toga proizlazi da se tako shvaćena sloboda ne može ostvariti, jer su prepreke u ostvarivanju i širenju takve slobode drugi ljudi, pravo i zakon. U knjizi Das Unbehagen an der Moderne [Nelagoda u moderni] (Taylor 1995) imenuje tri neugodne pojave u moderni. 1. Nestanak moralnoga horizonta, smisla i viših vrijednosti. Nekad su ljudi sebe smatrali sastavnim dijelovima obuhvatnijega kozmičkog poretka. Diskreditiranje ovoga poretka označeno je kao "raščaranje" svijeta (Entzauberung, Max Weber). Tim je procesom svijet izgubio svoju čarobnu snagu. Prvi je, dakle, uzrok nelagode individualizam, koji je, po shvaćanju mnogih, najviše dostignuće moderne civilizacije. Takva individualistička (negativna) sloboda postignuta je tako što smo se oslobodili od starijega moralnog horizonta, pa sada čovjeku nedostaje osjećaj za više vrijednosti, za koje se isplati živjeti i umrijeti. Ljudi danas teže isključivo za "ugodom koja pobuđuje sažaljenje" (erbärmliches Behagen, Friedrich Nietzsche). Na taj je način čovjekov život osiromašen jer je čovjek koncentriran samo na svoje $j a$. 2. Druga nelagoda moderne jest fenomen koji nazivamo primatom instrumentalnoga uma. Um služi samo kao instrument za pronalaženje sredstava koja služe za postizanje postavljenog cilja. Sve što postoji svedeno je na sredstvo za uporabu, pa tehnika ima dominantnu ulogu, što znači da je, na primjer, pacijent za medicinsku struku objekt obrade, a ne osoba: pacijent je, dakle, tehnički problem. 3. Treća se nelagoda sastoji u tome da individualizam i instrumentalni um u političkom životu vode ljude u blagi despotizam (Alexis de Tocqueville). Riječ je o vladi koja s građanima postupa blago i paternalistički te koja se tako pretvara u skrbnika svojih građana. To se odigrava u krajnje centraliziranom i birokratiziranom političkom svijetu.

Nadalje, u knjizi A Secular Age [Sekularno doba] (usp. Taylor 2007) dokazuje da u novom vijeku zlo više nije u čovjeku, dakle, zlo više nije endogeno, nego je egzogeno. Naime, zlo se sada nalazi izvan čovjeka: u sustavu, u povijesti, u strukturama, što će reći u stvarnosti izvan čovjeka. Time je čovjek sebe proglasio bezgrešnim i bezazlenim, a sva zla smjestio u druge: $u$ 
pripadnike drugih naroda, religija, kultura, politika i civilizacija. Taj bezgrešni čovjek danas ubija zlo u drugim ljudima bez grižnje savjesti. Bezazlene moderne ubojice svoja ubojstva drugih ljudi proglašavaju dobrim djelima. Ti bezgrešni ljudi ubili su milijune i milijune ljudi u ime dviju najopasnijih modernih ideologija: $u$ ime nacionalizma (u liku fašizma i nacizma) te $u$ ime komunizma (u liku staljinizma i u liku kineske i južnoazijske varijante komunizma). Takav moderni bezgrešan čovjek postao je amoralno biće, naprosto biće s onu stranu dobra i zla: on nema osjećaja za moralnu normu ni za moralnu obvezu. Moralna pitanja jednostavno su odsutna iz njegove svijesti. Što se prije zvala moralna filozofija ili etika sada se zove terapeutika. Dogodio se čuveni "terapeutski obrat" (therapeutic turn), što znači da zla nema u čovjeku, pa on nikada ne može biti kriv, nego može biti samo duševno bolestan. Umjesto moralnoga registra danas postoji terapeutski. Njime je umanjeno čovjekovo dostojanstvo, jer je čovjek postao puki objekt terapeutske obrade. Odbacujući skrbništvo religije (tj. Crkve i klera) moderni su ljudi željeli afirmirati svoje dostojanstvo, ali su sada potpali pod skrbništvo terapeutike, gdje ih tretiraju kao stvari i ušutkuju više nego nekada vjernike u crkvama. Ako je moderni čovjek nesposoban za grijeh (za zlo), nesposoban je i za slobodu i za odgovornost, jer grijeh (zlo) nastaje iz čovjekove slobode, a iz te slobode nastaje i čovjekova odgovornost. Time je proizveden kraj etike, o čemu su govorili mnogi marksisti, a danas govore mnogi scijentisti.

\section{B. Pascal Bruckner}

Francuski pisac i jedan od "novih filozofa" poznat po svojim kritikama (ne samo) francuskoga društva i francuske kulture. U svojoj knjizi Napast nedužnosti (usp. Bruckner 1997) pokazuje kako je došlo do nasilja na prostoru nekadašnje Jugoslavije. Ljudi i cijele skupine, cijeli narodi žele se osloboditi odgovornosti na dva načina: infantilizam i viktimizacija. To su dva simptoma današnjega čovjeka i današnjega društva. Infantilizam se sastoji u tome da se odrasli ljudi i cijeli narodi ponašaju infantilno, tj. kao razmažena djeca: čine zlo, a ne osjećaju se krivima, nego za počinjeno zlo očekuju priznanja i nagrade. Viktimizacija se očituje u tome da odrasli ljudi i cijeli narodi smatraju sebe žrtvama, koje su nesposobne za zlo. Oni navodno podnose tuđa zla, a od drugih očekuju priznanje njihove žrtve. 


\section{Robert N. Bellah}

Američki sociolog međunarodno poznat po svom radu u vezi sa sociologijom religije. U koautorskoj knjizi Habits of Heart [Navike srca] (Bellah et al. 1996) kritizira dva oblika američkoga individualizma pozivajući se na istaknutoga francuskog socijalnog filozofa Alexisa de Tocquevillea, koji je 1830. neke aspekte američke demokracije nazvao individualizmom. Bellah dokazuje da oba američka individualizma (utilitarni i ekspresivni) vladaju u američkom društvu, a za oba je individuum primarna realnost, dok je društvo sekundarna, tj. izvedena realnost.

\section{Peter Sloterdijk}

Svjetski poznat njemački filozof, televizijski voditelj i esejist. U svom trosveščanom djelu pod naslovom Sphären [Sfere] (usp. Sloterdijk 1998; 1999; 2004) tvrdi da je novovjekovni individualizam placentalan, jer u novom vijeku i pojedinci i sustavi funkcioniraju kao sveti egoisti. Kritizirajući individualizam Sloterdijk dokazuje da je ljudsko biće od samoga začetka "bipolarno biće", jer par predstavlja veličinu stvarniju od individuuma.

\section{E. Hans Jonas}

Istaknuti američko-židovski filozof, rođen u Njemačkoj, poznat po svojim djelima o gnosticizmu i etici odgovornosti. Davno je Jonas u knjizi Das Prinzip Verantwortung [Princip odgovornosti] (usp. Jonas 1984) dokazao da su znanost i tehnika postale najveća prijetnja prirodi, čovjeku i čovječanstvu. Nekada su one čovjeku obećavale spasenje, a danas mu nude propast, dakle, vode ga u uništenje i samouništenje. Povezane s ekonomijom (osobito s vojnom) i medijima one imaju dosad neviđenu moć. Zato je Jonas formulirao nov etički imperativ, koji glasi: "Djeluj tako da učinci tvoga djelovanja ne budu razaralački za permanentnost autentičnoga ljudskog života na Zemlji”, (Jonas 1984: 36).

\section{F. Edgar Morin}

Francuski filozof i sociolog, jedan od najpoticajnijih mislilaca današnjice. U knjizi Etika (usp. Morin 2008) upozorava nas da današnje čovječanstvo može završiti u barbarstvu umjesto u istinskoj civilizaciji i humanizaciji. On ističe da je odnos znanosti i tehnike postao toliko nerazdvojan da nam se danas 
naprosto nametnuo izraz tehnoznanost. Razvoj znanja radi spoznaje (to je znanstveni imperativ) postao je nerazdvojan od ovladavanja prirodom (to je tehnički imperativ). Treba dodati da se suvremena vladavina nad vanjskom prirodom pretvorila i u vladavinu nad čovjekovom prirodom. Znanost i tehnika u službi ekonomije (industrije, transporta i komunikacija) te znanstvena istraživanja na području kemije i genetike uvele su znanost u svijet profita. Tako je suvremena tehnoznanost najmoćniji pokretač društva. Znanost objašnjava strukturu atoma $i$ gena te time postaje moćno sredstvo za uništenje i manipulaciju u rukama političkih sila. Znanstvenici su lišeni moći koja se koncentrira u rukama velikih kompanija i državnih sila. Atomska je bomba izmakla kontroli znanstvenika. Znanost je danas prisutna na svim područjima i na svim razinama ljudskoga života, ima neograničenu moć, "ali je potpuno nemoćna da kontrolira vlastitu moć” (Morin 2008: 71).

\section{G. Hans Küng}

Najglasovitiji katolički teolog, a poznat i kao filozof, utemeljitelj dijaloga među religijama postavljenoga na principima svjetskog etosa. U knjizi Projekt Weltethos [Projekt svjetski etos] (usp. Küng 2006) tvrdi da svjetski etos vrijedi za sva područja i za sve razine ljudskoga života: za politiku, gospodarstvo, znanost, medije i ostala područja javnoga života. Potreban nam je globalan etos koji će vrijediti za cijeli svijet. Naime, etos nas oslobađa od svih ideologija koje crno-bijelo prikazuju stvarnost i tako proizvode taštinu, mržnju i nasilje.

\section{H. Žarko Paić}

Hrvatski sociolog i filozof, svestran intelektualac. U knjizi Politika identiteta. Kultura kao nova ideologija (usp. Paić 2005) zahtijeva pristup kulturi i ideologiji drukčiji od dosadašnjega, jer želi "deideologijazciju kulture i dekulturalizaciju ideologije” (Paić 2005: 209). Kultura je, po Paiću, postala univerzalna ideologija globalnoga kapitalizma. Trijada biopolitika identiteta - ideologija humanitarizma - genetska tehnologija određuju suvremeni globalni kapitalizam. U kulturu kao novu ideologiju spadaju i znanost, i religija, i umjetnost. U doba globalizacije došlo je do "kulturalnog obrata" (cultural turn), po kojem kultura postaje novom ideologijom novoga svjetskog poretka. Prema tome, suvremena kultura opravdava razvitak globalnoga kapitalizma, a time izdaje svoju bit (autonomiju, samousavršavanje i integraciju). Treba 
spomenuti da je Paić napisao peterosveščano djelo pod naslovom Tehnosfera (usp. Paić 2018-2019), u kojem se pita je li u tehnosferi moguć obrat prema humanizmu.

\section{Jürgen Habermas}

Glasovit njemački filozof u knjizi Glauben und Wissen [Vjera i znanje] (usp. Habermas 2001) ističe da znanost danas ima monopol na znanje o svijetu te da je znanost revolucionirala naše svakidašnje znanje. Ali, suvremena se znanost, u Habermasovu tumačenju, pretvorila u lošu filozofiju jer ukida razliku između opisivanja stvarnosti (što je zadaća znanosti) i opravdavanja stvarnosti (što je zadaća filozofije). Takva znanost ne priznaje čovjeka kao slobodno i odgovorno biće. U knjizi Dialektik der Säkularisierung [Dijalektika sekularizacije] (usp. Habermas / Ratzinger 2011) tvrdi o našoj civilizaciji da je ugrožena "sekularizacijom koja skreće s kolosijeka" (ibid.: 17), jer su presušili moralni izvori (osobito solidarnost). Zbog toga ustavna država želi sačuvati sve kulturne izvore "iz kojih se hrane svijet o normi i solidarnost građana" (ibid.: 33). Ako ljudi nisu svjesni moralne norme koja ih bezuvjetno obvezuje, prestaju biti moralna bića, tj. slobodna i odgovorna bića; ako su izgubili osjećaj solidarnosti i ako ih tuđa patnja ne pogađa, postali su moderni barbari.

\section{J. Yuval Noah Harari}

Izraelski intelektualac, strukom povjesničar, profesor povijesti u Jeruzalemu. Svoju knjigu Homo Deus. Eine Geschichte von Morgen [Homo Deus. Povijest sutrašnjice] (usp. Harari 2017) zaključuje tvrdnjom da u 21. stoljeću cenzura znači (umjesto nekadašnje zabrane) preplaviti ljude nevažnim informacijama. Ljudi tada naprosto ne znaju na što treba skrenuti pažnju, pa svoje vrijeme troše na bavljenje sporednim aspektima nekog problema. U prethodnim vremenima moć je značila pristup podacima, a danas znači znati što treba ignorirati, znati na što se u našem kaotičnom svijetu treba koncentrirati (usp. ibid.: 536). Harari najavljuje promjene na početku trećeg tisućljeća. Ističe da glad, bolest i rat čovječanstvo već sada može kontrolirati. Po prvi put u povijesti više ljudi umire od prejedanja nego od gladi; više umire od starosti nego od zaraznih bolesti; više je samoubojica nego žrtava kriminala, rata i terorizma. Početkom našega stoljeća prosječan će čovjek s većom vjerojatnošću umrijeti od prejedanja u McDonald'su nego od suše, ebole i napada Al-Kaide (usp. ibid.: 10). Moguće je, po Harariu, da ljudi postanu bogovi na tri načina: putem 
biotehnologije, putem cyborg tehnologije i putem proizvodnje neorganskih živih bića. Biotehnologija polazi od spoznaje da se razvoj kreće od amebe, preko gmazova i sisavaca, do homo sapiensa, a može ići i dalje od homo sapiensa. Cyborg tehnologija organsko će tijelo snabdjeti umjetnim rukama, očima i milijunima nanorobota (usp. ibid.: 64). Treći veliki projekt bit će da čovječanstvo sebi prisvoji božansku moć stvaranja i razaranja te da homo sapiensa uzdigne u homo deusa. Dakle, po Harariju, svi se projekti svode na jedan projekt: postići božanskost, ali ta božanskost je shvaćena više u smislu grčkih i hinduističkih bogova, a manje u smislu svemoćnoga Boga Biblije. Naši će potomci, pretpostavlja Harari, vjerojatno imati svoje vlastitosti, sklonosti i slabosti, ali će na posve drukčiji način moći voljeti, mrziti, stvarati i razarati (usp. ibid.: 69).

Pogledamo li ljudski život u cjelini, slijedeći Hararija, svi će problemi i razvoji biti u sjeni triju uzajamno povezanih procesa: 1. Pretvaranje znanosti u sveobuhvatnu dogmu koja tvrdi da su organizmi algoritmi, a da je život prerada podataka; 2 . Inteligencija se odvaja od svijesti; 3 . Nesvjesni, ali visokointeligentni algoritmi mogli bi nas već uskoro bolje poznavati nego mi sami sebe. Ta tri procesa nameću tri ključna pitanja: 1. Jesu li organizmi stvarno algoritmi i je li život stvarno prerada podataka?; 2. Što je vrednije - inteligencija ili svijest?; 3. Što nastaje iz našega društva, naše politike i našega svakidašnjeg života ako nesvjesni, ali visokointeligentni algoritmi poznaju nas bolje nego mi sami sebe? (usp. ibid.: 536-537).

\section{K. Otfried Höffe}

Njemački svjetski priznat moralni filozof, specijalist za filozofiju Immanuela Kanta. U petom poglavlju svoje knjizi Die Macht der Moral im 21. Jahrhundert [Moć morala u 21. stoljeću] (usp. Höffe 2014: 64-79) daje prikaz razvoja znanosti i tehnike u pet faza. uzmemo li u obzir povijest znanosti, tvrdi Höffe, vidjet ćemo da povijest znanosti (osobito povijest istraživanja prirode) pokazuje koje promjene u znanosti zahtijevaju razgovor s etikom, zapravo, koju vrstu etike zahtijevaju. Ovakav pristup ima dvije prednosti: ne podliježe opasnosti od moraliziranja koje je udaljeno od stvarnosti, nego počinje od istraživanja i proširuje etiku istraživanja poznatom kritičkom etikom i kontrolnom etikom. Pogledamo li povijest znanosti u bitnim crtama, možemo razlikovati pet faza, od kojih svaka ima svoj karakterističan odnos prema etici. Na starom Istoku bilo je, moralno gledano, lako sa znanošću. Medicina, astronomija, matematika i plansko promatranje bili su u službi ljudskoga života, pa je razgovor s 
etikom bio suvišan. Jedino se može prigovoriti da su rezultati znanosti služili tankom društvenom sloju: vladaru, njegovoj obitelji, plemstvu i visokim činovnicima, kratko rečeno, znanost je tamo bila humanitarna, ali nepravedna.

U drugoj fazi Höffe tvrdi da iza enormnoga napretka u grčkom prostoru stoji epistemska revolucija koja je usmjerena na znanje, tj. na otkrivanje logičkog poretka koji je već bio pripremljen na starom Istoku. Ta revolucija razvlašćuje mit u ime logosa. Dva aspekta (dva evolucijska pomaka) te revolucije ovdje valja istaknuti. Znanstvenoteoretski pomak oduzima znanju karakter recepta i čini ga preispitivim tako što se ono može prenositi dalje poučavanjem i učenjem. Znanje je u punom smislu određeno općim pojmovima, razlozima, uzrocima i zakonima. Da bi se ostvario prvi aspekt revolucije potreban je i drugi aspekt, tj. intencionalna revolucija, po kojoj je istraživanje slobodno od koristi na dva načina: ono inicira novu vrstu etike istraživanja, etiku koja inicira i legitimira istraživanje, te sužava rang danas dominantno humanitarnoga znanja.

Znanost spoznaje najviše i najopćenitije uzroke i razloge te teži za spoznajom radi spoznaje. Kao što slobodan čovjek, za razliku od roba, živi radi sebe, tako i u spoznajnom smislu slobodno se znanje traži radi sebe. U taj rang spada ne samo Prva filozofija, koju kasnije nazivamo metafizikom, nego i matematika, astronomija, teoretska fizika i biologija. Istraživanje ne služi vanjskim interesima ni vanjskim obvezama. Druga epistemska revolucija povezana je s moralnom revolucijom, s moralnim evolucijskim pomakom. Želja za znanjem pripada naravi čovjeka obdarena razumom i zato epistemsko slobodno istraživanje ima humani i istodobno moralni rang. Takvo istraživanje ispunjuje kriterije antičkoga moralnog principa (eudaimonia), sreće u najvećoj mjeri. U slobodnom istraživanju usavršava se i ostvaruje čovjekova razumna narav, a to se zove sreća. Kod Grka epistemsko slobodno istraživanje dobra ima najviši moralni rang. Tko se bavi filozofijom ili istraživanjem prirode, vodi dobar život (eu zen), sretan i uspješan život. To čini jezgru etike znanosti i etike istraživanja. Takva etika afirmira znanost jer ona inicira i legitimira istraživanje, potvrđuje slobodno istraživanje kao najvišu formu humanog života. Veliki zastupnik takve etike bio je Aristotel, koji ne poriče vrijednost očeva liječničkoga poziva, ali na vrhu hijerarhije znanosti stoje isključivo filozofija i znanost koja nije utilitarna ni humanitarna.

Aristotel nije zanemario mnogostrukost prirode, jer on pokazuje da i najniže životinje u svojoj svrsishodnosti imaju na sebi nešto vrijedno divljenja. To divljenje beskonačnom bogatstvu prirode upućuje na treći epistemski evolucijski pomak. Sam Charles Darwin naziva Aristotela jednim od najvećih, 
ako ne i najvećim promatračem prirode. Grci su u medicini postigli značajan dijagnostički i terapeutski napredak. Učinili su drugi evolucijski pomak: svečanu samoobvezu liječnika. U njoj naznačuju drugu etiku istraživanja, čak kontrolnu etiku. Hipokratski liječnik se podvrgava dvjema moralnim obvezama. Prva hipokratska zapovijed sadržava treći razlog koji legitimira i ujedno kontrolira istraživanje. To je prvi element kontrolnoga morala: dobro pacijenta najviši je zakon (salus aegroti suprema lex). Druga obveza postavlja granicu zabranom da se ne smije nikome škoditi (nil nocere). Novija medicinska etika ovim načelima dodaje i treće: zapovijed prosvijećenoga pristanka.

U trećoj fazi, po Höffeu, dolazi do sukoba između prirodne želje za znanjem i znanja koje dolazi iz božanske Objave. Ovdje želim dopuniti autora novim spoznajama. Treba, naime, reći da je bilo pretjerivanja na obje strane: $i$ na strani prirodnoga uma, i na strani vjere (Objave). Neki su htjeli svesti vjeru na znanje, a drugi znanje na vjeru. Oboje je nasilno. Pravo se rješenje nalazi u postizanju sklada između uma i vjere. Nova istraživanja srednjovjekovne filozofije i teologije pokazuju da je već kod velikih franjevačkih teologa i filozofa došlo do primata praktičnog (moralnog) intelekta pred spekulativnim (teoretskim). To je jasno iskazano kod Rogera Bacona, za kojega je moralna filozofija vrhunac filozofije, jer je praktični intelekt ili slobodna volja intelekt slobode, iz koje nastaje odgovornost. Time je obrnut hijerarhijski redoslijed znanosti koji je vladao kod Aristotela: teoretske, praktične i poietičke znanosti. Kod Bacona, Ivana Duns Škota i Vilima Ockhama prednost imaju praktične znanosti pred teoretskima (usp. Babić 2015: 67-86). U svojoj povijesti filozofije J. Habermas dokazuje da su dvojica franjevačkih velikana u srednjem vijeku ( $\breve{S} k o t$ i Ockham) začetnici moderne paradigme, tj. modernoga puta (via moderna), jer stavljaju skretnice za znanstvenu, religioznu i društveno-političku modernu (usp. Habermas 2019: 761-851). Glasoviti istraživač srednjovjekovne filozofije Ludger Honnefelder tvrdi da su glavne karakteristike Škotove filozofije intencionalnost, transcendentalnost i moralnost. Svojim poimanjem slobode $\breve{S} k$ t utemeljuje svoju etičku teoriju, koja je s onu stranu voluntarizma i naturalizma (usp. Honnefelder 2005).

U četvrtoj fazi Höffe pokazuje kako se nasuprot antici i srednjem vijeku razvija istraživanje u ranom novom vijeku. Glavno djelo proroka znanstveno-tehničke civilizacije Francisa Bacona Instauratio magna odnosno Novum organum (1620) ima na naslovnoj stranici sliku broda koji se vraća sa svoga putovanja po bezgraničnom oceanu u morski tjesnac. Time su očito naznačena dva evolucijska pomaka karakteristična za novi vijek: brod se oslobađa užadi morskoga tjesnaca i tako simbolizira intelektualnu emancipaciju koja 
uključuje neograničeno slobodnu volju za znanjem. Nasuprot Prvoj filozofiji, koja traga za najvišim znanjem, za najopćenitijim uzrocima i razlozima, sada nastupa humanitarno obvezatna inovacija: pustolovina otkrivanja na bezgraničnom oceanu. Kod istraživanja Bacon inzistira na preispitivim eksperimentima. U tom evolucijskom koraku Kant je vidio epistemsku revoluciju, koja se sastoji u tome da istraživači prirodu ne promatraju pasivno, nego je aktivno obrađuju. Istraživači postavljaju ili izmišljaju precizna pitanja prirodi, hipoteze, te s pomoću zahvata, eksperimenata, prisiljavaju je na odgovor. I Bacon i Kant, međutim, zanemaruju moralne posljedice takvoga istraživanja, jer istraživanje koje zahvaća u svijet života nameće odgovornost za takvo djelovanje, za rizike koji nastaju takvim zahvaćanjem u prirodu. Bacon od znanstvenika zahtijeva da nauče gledati prirodu na posve nov način, kao mala djeca, da budu slobodni od predopterećenja i od predrasuda. Treba reći da mala djeca žive bez predopterećenja, ali i u određenom pogledu djeluju ne misleći, tj. ne zamjećuju negativne posljedice i previđaju troškove svoga pothvata.

Dugo je novi vijek pokušavao svojim inovacijama dodijeliti karakter nedužnosti. Mora se priznati da su eksperimenti kakav je Galilejev s padom kamena bili nedužni jer ispunjuju pet uvjeta: 1. Eksperimenti se provode u maloj mjeri; 2. i to na neživoj materiji; 3. promjene koje oni izazivaju u prirodi mogu se dobro unaprijed procijeniti; 4. ne nanose nikakvu veliku štetu; 5 . pričinjavaju samo reverzibilnu štetu. Baconov treći evolucijski pomak sastoji se u tome da on ne obnavlja antički ideal slobodnoga istraživanja, jer kod njega istraživanje ima humanitarnu svrhu. U njegovoj znanstvenoj utopiji Nova Atlantida (1627) istraživačka republika traži sredstva protiv gladi, pošasti i bolesti, i to pod devizom: "medicina umjesto metafizike". Dakle, u humanitarnom smislu istraživanje je bezgranično. U svom djelu Instauratio magna Bacon tvrdi da se ne može pretjerati u ljubavi u humanitarnom istraživanju. Novovjekovno je istraživanje odgovorno za dvije stvari: 1. suodgovorno je za promjenu stava, tj. za novo utilitarističko razumijevanje sebe i svijeta; 2. odgovorno je za ispunjavanje svoga humanitarnog obećanja. Jedan od prvih Baconovih velikih pristaša René Descartes pretpostavljao je "da bi se moglo osloboditi od beskonačno mnogih bolesti, kako tijela tako i duha, možda čak i od starosti”. Posebno ekstreman primjer neozbiljnih očekivanja nudi Kongres vodećih molekularnih biologa održan u Londonu 1962, koji je očekivao oslobođenje svijeta od zaraznih bolesti, život bez patnje, i - zahvaljujući transplantaciji organa - beskonačan život, što znači poboljšanje genetske opskrbe. Etika kao kritika ideologije odbacuje podmetanje svemoći. Već je sam Bacon kritizirao neka biomedicinska istraživanja koja su željela imati ulogu 
Boga, koji je stvorio svijet u šest dana, a sedmi se dan odmarao. Čovjek ne može stvoriti prirodu iz ništa (ex nihilo) kao Bog i ne može se sedmi dan odmarati te gledati na ono što je stvorio kao dobro. Čovjekova želja za znanjem ne može se zasititi (to mu je urođeno), i njegov interes da olakša i poboljša ljudski život ostaje stalan. Ali, ljudsko stvaranje nije nikad tako dobro da ga nije moguće dalje usavršavati niti je sekularni raj moguć za čovjeka.

U petoj fazi razvoja znanosti Höffe pokazuje da najnovija istraživanja zahtijevaju odgovornost jer mijenjanju prirodu i jer su posljedice istraživanja ireverzibilne, što znači da je nastalu štetu nemoguće popraviti. Nemoguće je suzbiti radioaktivno zračenje, što je očito i kod atomskih eksperimenata. Galilei je u svom eksperimentu morao paziti samo toliko da nitko ne prolazi putem na koji pada kamen, a sam je kamen poslije mogao vratiti na mjesto $\mathrm{s}$ kojega ga je uzeo. Okvirni uvjeti istraživanja u ranom novovjekovlju znatno su prekršeni u istraživanju gena. Tu se eksperimentira osnovnim elementima života i ne mogu se procijeniti posljedice za svijet izvan laboratorija. A posljedice mogu biti sudbonosne epidemije. Filozofska etika ne može odlučivati o opasnosti koje nam prijete, ali može imenovati odgovornost koja je primjerena takvom istraživanju i pritom razviti kontrolnu etiku i etiku rizika. Treba istražiti vrste opasnosti koje nam prijete (posve nepoznate i zbog toga neugodne) i rizike (koje su svladivi ili nisu) tako što se poduzimaju biološke i fizikalne mjere opreza. Ne naposljetku treba se pitati o cijeni i moneti kojima se plaćaju eksperimenti. Treba uzeti u obzir personalne, socijalne i čak estetske troškove. Pritom rizike treba određivati ne ahistorijski, nego samo u ovisnosti o konkretnoj kulturi. Etika rizika odnosi se ne samo na personalni lik morala, nego i na socijalne mjere koje su potrebne, ali moraju biti fleksibilne kako ne bi gušile kreativnost istraživanja. Međunarodna istraživačka zajednica može pritom biti od pomoći kod uspostave internacionalno vrijedećih pravila tako da nacionalni zakonodavci ne zakidaju svoje istraživače.

Također, u suvremenom istraživanju postaje važan drugi evolucijski pomak novoga vijeka: humanitarna znanost. Sve do 19. stoljeća mnoga istaknuta istraživanja služila su primarno spoznaji. Tako su Newtonovi zakoni, Darwinova teorija evolucije, kvantna teorija i teorija relativnosti, čak dešifriranje DNK bile motivirane čistom željom za znanjem, a ne humanitarnim poticajima. Danas je dominantna protusmjer, jer je nastupila epoha znanosti života, od kojih se očekuje viša korist. Dešifriranje genetskoga koda markira strukturalnu promjenu. Ona se sastoji u novom redoslijedu teorije i prakse, jer se fundamentalno istraživanje može u kratkom vremena pretvoriti u novovrsnu tehniku. Tehnički upotrebljivi bili su već zakoni Gregora Mendela, 
austrijskoga svećenika i znanstvenika, a oni su nudili samo teoretsku nadgradnju već davno prakticiranoj tehnici, tradicionalnom uzgoju biljaka i životinja. U molekularnoj biologiji obrće se redoslijed: sada teorija prethodi tehnici. Temeljno istraživanje skoro stvara mogućnosti primjene koje se nastoji što više iscrpsti radi imperativa bezgraničnog poboljšanja. Potrebno je, doduše, još međuistraživanje, odnosno istraživanje temelja primjene. Tu je potrebna etika kao kritika ideologije. Tko već za međuistraživanje, na primjer, embrionalnih stanica, zahtijeva humanitarni dobitak, nije samo neozbiljan, nego izvodi i humanistički pogrešan zaključak. On se, naime, poziva na mogućnost pomoći pacijentima, premda se tek bavi predradnjama. U ovom slučaju vrijedi zapovijed: teško bolesnim pacijentima i njihovoj rodbini, koji se hvataju za slamku spasa, ne smiju se davati nikakva otvorena obećanja. Čak netko tko im može obećati nove mogućnosti pomoći ne pruža im još nikakvu aktualnu pomoć. Tko tu razliku prešućuje izvodi drugi humanistički pogrešan zaključak. Neozbiljna je i stanovita procjena epistemske inovacije, na primjer, ako je dešifriran ljudski genom, nije dešifriran sam čovjek. U vrijeme buma znanosti života ne smiju se zaboraviti filozofija i humanističke znanosti. Blagodati medicine dobro su došli svim građanima, ali one su rezultat izvanjskoga istraživanja, tj. zakonskog osiguranja bolesnika, općenito socijalne države, čije opravdanje podliježe socijalnoj etici.

Molekularna biologija kreće se prema petom evolucijskom pomaku, koji možda ima tri gledišta: 1. kod čovjeka bi molekularnobiološki odnosi mogli biti kompliciraniji od odnosa u podljudskom području: 2. zdravlje je elementarno dobro, pa istraživanje ima humanitarni rang; 3. jedino čovjek ima rang samosvrhe, koju nazivamo ljudsko dostojanstvo, pa zato s obzirom na sredstva postoji viša moralna odgovornost. Kao primjer nudi se medicinski potpomognuta oplodnja. Etika se najprije pita je li dopušteno ograničiti moć sudbine, zatim traži argumente koji u okviru oplodnje za dijagnostiku predimplantacije govore za i protiv. Napokon, etika razlikuje pitanje što zakonodavac može iznuditi od pitanja što se smatra ispravnim i što u danom slučaju savjetuju prijatelji i rodbina. Time filozofska etika razlikuje moral prava (ono što smo dužni činiti) i moral kreposti (ono što činimo više od zapovjeđenoga). U ime morala kreposti ne smije se povrijediti moral prava; u ime zapovijedi pomoći drugome ne smije se ubijati ničiji život. Kratko rečeno, ne smije se škoditi životu (nil nocere). 


\section{Günther Mack}

U svom tekstu pod naslovom "Die Suche nach einem zukunftsfähigen Wissenschafts-Paradigma" [Traganje za paradigmom znanosti sposobnom za budućnost] (usp. Mack 1998: 308-329) tvrdi da je znanost kulturna aktivnost čija oblikovna moć (Machtförmigkeit) raste. Moć znanosti, prema tome, raste na svim područjima kulture, društva i politike, osobito na području ekonomije i vojne industrije. Šire se osjećaji straha od znanstveno-tehničkih posljedica, koji idu sve do neprijateljstva prema znanosti i tehnici. Dosad su bile zanemarene posljedice znanosti i tehnike, kao i posljedice njihovih posljedica. To su problemi naoružavanja (atomsko, biološko i kemijsko oružje), ekološka ugroženost čovječanstva i katastrofe (klimatske promjene, ozonska rupa, krčenje šuma i pustošenja, kemijske pošasti, izumiranja vrsta itd), informacijska i genetska tehnologija, rast stanovništva kao i ekonomski, društveni, socijalni i politički sukobi. O tome je potrebno posve nanovo razmisliti i pokrenuti promjenu svijesti o tome da bismo postigli minimalan konsenzus o najvišim vrijednostima i zajedničkim ciljevima. $U$ tom je najvažnija promjena $u$ poimanju znanosti, nova paradigma znanosti koja će zamijeniti dosadašnju paradigmu znanosti slobodne od vrijednosti, koja nije bila odgovorna ni za svoje primjene ni za svoje posljedice. Zbog toga nije bilo moguće proglasiti znanost odgovornom jer je ona obvezana na čistu spoznaju i na nalaženje istine te zato što njezine primjene u tehnici nisu njezina stvar, premda te primjene mijenjaju svijet, ugrožavaju sve i donose katastrofu. Diskusija o etici i zahtjevu da znanost i tehnika moraju imati odgovornost za sadašnje i buduće posljedice svoga ambivalentnog djelovanja simptom je prijeloma. Poticaj za promjenu razumijevanja znanosti dolazi iz same znanosti, ali i izvan nje. Kriza se znanosti ne smije promatrati kao izoliran fenomen jer je kriza morala danas sveobuhvatna. Ona pogađa sva područja kulturnoga i prirodnoga svijeta (svijeta života). Zavedeni smo modernom civilizacijom zahvaljujući njezinu znanstveno-tehničkom napretku, ali zavedeno je i cijelo društvo i mi sami.

Znanost je danas u visokom stupnju organizirana internacionalno, pa su zato njezine posljedice najvećim dijelom globalne. Zbog toga pitanje o paradigmi znanosti sposobnoj za budućnost uključuje raspravu o svjetskom etosu. Znanost sposobna za budućnost pretpostavka je civilizacije sposobne za budućnost. Vrijedi i obratno. Pitanje o budućnosti znanosti jest pitanje supradisciplinarne vrste. Uzrok krize znanosti jest etos znanosti koji je bio usmjeren na unutarnje upravljanje znanošću i s njom povezane predodžbe o slobodi od vrijednosti i o slobodi znanosti. Naime, znanost nije imala nikakav odnos sa 
svojim primjenama. Mack navodi kako je Robert K. Merton opisao "čistu" znanost: znanje je opće dobro (donum commune); znanstveno znanje vrijedi za sve ljude (ono je, dakle, univerzalno); ne obvezuju ga nikakve izvanznanstvene ideologije ni interesi (nezainteresiranost); znanstveno znanje se stalno izlaže kritičkom preispitivanju po znanstvenim metodama i mjerilima. U toj nezainteresiranosti (slobodi od vanjskih ideologija i interesa) vidi se najbolje da znanost sebe razumijeva kao slobodnu od vrijednosti (wertfrei). Time se isključuju izvanznanstvene i supradisciplinarne posljedice znanstvene djelatnosti. Princip vrijednosno neutralne znanosti zanemaruje interdisciplinarne i supradisciplinarne dimenzije znanosti. Znanost slobodna od vrijednosti u praksi je bila više fikcija nego realnost, jer je i sam Max Weber ustanovio da je teško odvojiti vrednovanja od empirijskih konstatacija. Ne može se govoriti o nezainteresiranosti "čiste", slobodne i od vrijednosti slobodne znanosti, jer znanost i istraživanje u svom su realnom socijalnom liku nerazdvojivo povezani i aktivno isprepleteni u znanstveo-tehničko-ekonomskom kompleksu. Kao primjer dostatno je spomenuti da je fundamentalno istraživanje u radiokemiji i u atomskoj fizici oslobodilo revolucionarnu, politički prevratničku opasnost i moć. Tako je i s istraživanjem gena, što vodi radikalnim promjenama. Ljudi iz gospodarstva, društva i politike zahtijevaju produktivnu snagu i kompetentnost za rješavanje problema (zapravo korist), a to čak ni zastupnici teze o znanosti slobodnoj od vrijednosti ne primjećuju.

Diskrepancija između samoograničenja znanosti u tradicionalnom etosu i društvene orijentiranosti na praksu pripada uzrocima krize, jer znanost čuva svoju unutarnju slobodu, dok kritičko vrednovanje njezinih posljedica dolazi od društvenih instancija, što ugrožava autonomiju znanosti. Znanost i istraživanje, osim kompetencije za rješavanje problema, mogu imati i potenciju za proizvođenje problema. Zato se znanost ne može više opravdavati načelima tradicionalnog etosa. Ne može se govoriti samo o odgovornosti znanstvenika (individualnoetički), nego i o odgovornosti znanstvene zajednice u institucijama i organizacijama. Potrebne su sankcije za znanstvenike i institucije koji djeluju protivno etici. Današnja kriza morala u znanosti ne može se riješiti unutar dosadašnje paradigme, pa je potrebno uspostaviti novu. Nova znanost treba biti otvorena drugim znanstvenim disciplinama (interdisciplinarna) i onome što nadilazi sve znanstvene discipline (transdisciplinarna). Potrebno je kvalitativno i kvalitativno proširenje njezina horizonta, koje uključuju njezinu odgovornost. Konture paradigme znanosti koja će biti sposobna za budućnost uključuju priznanje vrijednosnoga karaktera znanstvenoga spoznavanja i djelovanja. Vrijednost je sastavni dio znanosti, što znači da odgovornost 
bitno pripada znanstvenom spoznavanju i djelovanju. Ne zahtijeva se samo negativna sloboda $o d$, nego i pozitivna sloboda, sloboda za više vrijednosti. Odgovornosti pripadaju interdisciplinarnost, transdisciplinarnost i javnost rada.

Odgovorno znanstveno djelovanje očituje se u unutarnjoj, institucionalnoj i javnoj odgovornosti, koja uključuje procjenu posljedica istraživanja, posebno kad je riječ o naoružavanju, istraživanju gena i genetskoj tehnologiji. Pritom je važno odrediti ciljeve istraživanja, koji će biti u skladu s osobnim i institucionalnim etosom. I u sumnji - kako je govorio Hans Jonas - treba dati prednost proroštvu propasti. Znanstveno-tehničkoj odgovornosti pripada i odgovarajući nauk o tome, zatim institucionalni uvjeti, etičke komisije, ljudi ovlašteni za zaštitu etike, društva i udruženja. Uloga znanosti u društvu i politici sastoji se u tome da traga za temeljnim etičkim konsenzusom, s društvom i politikom. Pritom je važan znanstveni žurnalizam, koji će javnosti davati kvalificirane informacije, a ne senzacije. Što trebamo činiti, pita se na kraju svoga teksta Günther Mack i odgovara da to pitanje nadilazi znanost. Mack citira Leona Eisberga, evangeličkoga župnika koji radi sa studentima, koji kaže da je ideja bratstva u našem vremenu preduvjet našega preživljavanja. Valja nam, dakle, ponovno otkriti ideju bratstva.

\section{Zaključak}

Iz dosad izloženoga zaključujem sljedeće. Sve do novoga vijeka čovjekova je spoznaja uglavnom bila receptivna i čovjek je uglavnom bio pasivno biće. Zbog toga su nepravde čovjeku mogle nanijeti samo aktivne sile: prirodne i više sile. Naime, aktivni je princip bio važniji od pasivnoga. Tek u novom vijeku čovjekova spoznaja postaje aktivna, pa čovjek postaje primarno aktivno biće koje mijenja prirodu (svijet oko sebe) i sam sebe. To se dogodilo kopernikanskim obratom u novom vijeku, kad je čovjek, zahvaljujući prirodnim znanostima i tehnici, ovladao ne samo vanjskom prirodom, nego i svojom vlastitom. U znanstveno-tehničkoj civilizaciji znanost je stekla monopol na znanje o svijetu, a sada se nastoji pretvoriti u sveobuhvatnu dogmu. Njoj se može suprotstaviti samo moć morala koja mora biti globalna jer je i moć znanosti globalna.

Moderna društva, po Otfriedu Höffeu, žive od pretpostavki koje sama ne mogu garantirati (usp. Höffeu 2014: 194). Tom se tvrdnjom Höffeu oslanja na tvrdnju Ernsta-Wolfganga Böckenfördea, koji je davno ustvrdio da slobodarska sekularizirana država živi od pretpostavki koje ona sama ne može 
garantirati (usp. Böckenförde 1991: 112). Pretpostavke bez kojih ne možemo živjeti jesu temeljna vrijednosti: pravda, istina, sloboda, odgovornost, jednakost i bratstvo. U bit ljudskog bića spadaju sloboda i odgovornost. Ako se čovjek odrekne slobode i odgovornosti, odrekao se svoje vlastite biti, tj. samoga sebe, odrekao se svoga humanuma, onoga što ga čini čovjekom.

Potrebno nam je novo poimanje znanosti, koje priznaje da su sloboda i odgovornost imanentne svakom ljudskom spoznavanju i djelovanju. Sloboda i odgovornost nedjeljive su onako kako su danas nedjeljive znanost i tehnika. Da bismo promijenili poimanje znanosti potrebna je promjena svijesti pojedinca. Tajna je u tome što se ta promjena ne može iznuditi silom i strahom. Takva je promjena moguća samo iz slobode, a vrhunska sloboda je pozitivna sloboda, ona koja nastoji ostvariti najviše vrijednosti i ona koja nas povezuje s drugima u jednu zajednicu. Hannah Arendt tvrdi da je Ivan Duns Škot, najveći franjevački srednjovjekovni mislilac, ujedno i najveći filozof slobode u zapadnom mišljenju i da se samo Kant može s njim izjednačiti u bezuvjetnoj odanosti slobodi (usp. Arendt 1998: 376). Naime, Škot je dokazao da u ljudskoj slobodnoj volji postoje dvije sklonosti: sklonost vlastitoj koristi i sklonost pravdi. Obje su sklonosti (težnje) slobodne. Sklonost pravednosti je urođena sloboda, po kojoj naša volja može htjeti neko dobro koje nije usmjereno na nas, tj. po kojoj naša volja ne traži svoju korist, nego ono što nadilazi našu korist, našu sebičnost i egocentričnost. Sklonost pravdi je uzvišenija od sklonosti vlastitoj koristi, jer voljeti pravdu radi pravde, drugoga radi drugoga, slobodniji je i komunikativniji čin od čina ljubavi prema vlastitoj koristi. Takav čin pozitivne slobode oslobađa nas od egoizma i povezuje nas s drugim ljudima i takva sloboda neizravno govori o ideji bratstva, koja je preduvjet za preživljenje čovječanstva (usp. Babić 2012: 54-55; Duns Škot 2012: 154-157).

Za Škota je prirodno djelovanje nužno, ali sebično, dok samo slobodnim djelovanjem koje poštuje drugoga kao drugoga možemo nadići prirodnu nužnost i sebičnost. U svojoj knjizi Reportatio Parisiensis examinata on tvrdi da se sloboda može dokazati aposteriorno i da bez slobode ne bi bile potrebne ni kreposti, ni zapovijedi, ni opomene, ni nagrade, ni kazne, ni časti, te da ne bi bila moguća bila koja ljudska zajednice (ni politička, ni religiozna). Sloboda je, dakle, pretpostavka politike, morala i soteriologije. Pritom Škot ima na umu slobodu koja je slobodna od egoizma i koja je komunikativna jer nas povezuje u jednu zajednicu (usp. Babić 2019: XXI-XX; Duns Scotus 2005: 78-80). Kratko rečeno, istinska se sloboda ostvaruje u moralu i ljubavi. 


\section{Literatura}

Arendt, Hannah (1998). Von Leben des Geistes. Das Denken. Das Wollen, München/Zürich: Piper.

Babić, Mile (2012). "Sloboda kao affectio commodi i affectio iustitiae kod I. D. Škota", u: Ivan Duns Škot, Sloboda uzvišenija od nužnosti, priredio, s latinskoga preveo, tumačenja dodao i bilješkama popratio Mile Babić, Zagreb: Naklada Breza, str. 53-55.

Babić, Mile (2019). “Život i djelo Ivana Dunsa Škota”, u: Ivan Duns Škot, O principu individuacije, priredio i preveo Mile Babić, Zagreb: Demetra, str. XI-XXV.

Bruckner, Pascal (1997). Napast nedužnosti. Esej, prevela Višnja Machiedo, Zagreb: Nakladni zavod Matice hrvatske.

Bellah, Robert N. et al. (1996). Habits of Heart. Individualism and Commitment in American Life, Berkeley/Los Angeles/London: University of California Press.

Dahrendorf, Ralf (2009). "Nach der Krise: Zurück zur protestantischen Ethik? - Sechs Anmerkungen", u: Merkur 63/720, str. 373-381.

Duns Scotus, Johannes (2005). Pariser Vorlesungen über Wissen und Kontingenz. Lateinisch - Deutsch. Reportatio Parisiensis examinata I 38 - 44, herausgegeben, übersetzt und eingeleitet von Joachim R. Söder, Freiburg/Basel/ Wien: Herder.

Duns Škot, Ivan (2012). Sloboda uzvišenija od nužnosti, priredio, s latinskoga preveo, tumačenja dodao i bilješkama popratio Mile Babić, Zagreb: Naklada Breza.

Görlach, Alexander (2019). Homo empathicus. Von Sündenböcken, Populisten und der Rettung der Demokratie, Freiburg/Basel/Wien: Herder.

Habermas, Jürgen (2001). Glauben und Wissen, Frankfurt am Main: Suhrkamp.

Habermas, Jürgen / Ratzinger (2011). Dialektik der Säkularisierung. Über Vernunft und Religion. Freiburg/Basel/Wien: Herder.

Habermas, Jürgen (2019). Auch eine Geschichte der Philosophie. Band 1: Die okzidentale Konstellation von Glauben und Wissen, Frankfurt am Main: Suhrkamp.

Harari, Yuval Noah (2017). Homo Deus. Eine Geschichte von Morgen, München: C. H. Beck.

Höffe, Otfried (2014). Die Macht Moral im 21. Jahrhundert. Annährungen an eine zeitgemässe Ethik, München: C. H. Beck.

Jonas, Hans (1984). Das Prinzip Verantwortung. Versuch eine Ethik für technologische Zivilisation, Frankfurt am Main: Suhrkamp.

Küng; Hans (2006). Projekt Weltethos, München/Zürich: Piper.

Mack, Günther (1998). "Die Suche nach einem zukunftsfähigen Wissenschafts-Paradigma", u: (ur.) Hans Küng, Karl-Josef Kuschel, Wissenschaft und Weltethos, München/Zürich: Piper, str. 308-329.

Morin, Edgar (2008). Etika, prijevod Vesna Pavković, Zagreb: Massmedia.

Paić, Žarko (2005). Politika identiteta. Kultura kao nova ideologija. Zagreb: Izdanja Antibarbarus.

Paić, Žarko (2018-2019). Tehnosfera. Zagreb: Sandorf - Mizantrop.

Sloterdijk, Peter (1998). Sphären. Mikrosphärologie. Band I: Blasen, Frankfurt am Main: Suhrkamp.

Sloterdijk, Peter (1999). Sphären. Mikrosphärologie. Band II: Globen, Frankfurt am Main: Suhrkamp.

Sloterdijk, Peter (2004). Sphären. Mikrosphärologie. Band III: Schäume, Frankfurt am Main: Suhrkamp.

Taylor, Charles (1994). Quellen des Selbst. Die Entstehung der neuzeitlichen Identität, übersetzt von Joachim Schulte, Frankfurt am Main: Suhrkamp. 
Posebna izdanja ANUBiH CC, ODN knjiga 18, str. 79-98

Taylor, Charles (1995). Unbehagen an der Moderne, übersetzt von Joachim Schulte, Frankfurt am Main: Suhrkamp.

Taylor, Charles (1998). Negative Freiheit? Zur Kritik des neuzeitlichen Individualismus, übersetzt von Hermann Kocyba, Frankfurt am Main: Suhrkamp.

Taylor, Charles (2007). A Secular Age, Cambridge/Massatchusetts/London: The Belkamp Press of Harvard University Press. 